\title{
Improvement the california bearing ratio of expansive subgrade using $\mathrm{SiCC}$ column
}

\author{
Agus Setyo Muntohar ${ }^{1,}$, Willis Diana $^{1}$, Edi Hartono ${ }^{1}$, and Anita Widianti ${ }^{1}$ \\ ${ }^{1}$ Department of Civil Engineering, Universitas Muhammadiyah Yogyakarta, D.I. Yogyakarta, \\ Indonesia
}

\begin{abstract}
In Indonesia, many main roads have been constructed on problematic soil. The chemical improvement is widely used to shallow soil modification and stabilization. This paper introduces the use of a SiCC column to strengthen the load-bearing capacity of the expansive soil. In the road pavement design, California Bearing Ratio (CBR) is a most useful parameter to define the pavement layers. Hence, this paper is aimed to investigate the effect of SiCC column on the CBR of compacted expansive soil. Two groups of specimens were prepared for CBR test under soaked condition. A set of specimens are prepared on the wet side (Specimen A), and a set of specimens are compacted on the dry side of optimum moisture content (Specimen B). The objective of this research is to determine the effect of moisture content and dry density on the CBR value. The experiment results show that the SiCC column significantly increases the CBR of expansive soil on both dry and wet side of optimum moisture content. The specimen compacted on the dry side exhibit a higher CBR than the specimen compacted on the wet side of optimum moisture content.
\end{abstract}

\section{Introduction}

In Indonesia, many roads have been constructed on expansive soil such as the Surabaya Bojonegoro, Caruban - Ngawi, and Indramayu - Pamanukan roads [1,2]. Those roads used the rigid pavement and modified rigid pavement supported with mini piles named as "Cakar Ayam Modikasi "(CAM). The use of rigid pavement system fulfils the technical aspect of the highway. However, the construction cost was very expensive, about Rp 4-5 billion $/ \mathrm{km}$ compared to Rp. 1-1.8 billion/ $\mathrm{km}$ for flexible pavement systems [3].

The chemical improvement method in expansive soil by using lime has been widely applied. Generally, lime is mixed into expansive subgrade, and compacted at a particular water content $[4,5]$. Other techniques are a lime-column method such as those applied by Muntohar [6], Budi [7], Muntohar and Liao [8], and Tonoz et al. [9]. However, the lime column technique is directed to deep soil improvement which has a diameter of $1.2 \mathrm{~m}$ and a depth of up to $20 \mathrm{~m}[10,11]$. In addition, this column technique can also be used as a

\footnotetext{
*Corresponding author: muntohar@umy.ac.id
} 
foundation for building structures [12]. However, the application of this column technique is still needed to be studied for pavement structures [13,14].

Muntohar and Saputro [15] used SiCC column made of microsilica and microcalsium to improve the unconfined compressive strength of expansive clay. Furthermore, Muntohar [13] analyzed the SiCC columns numerically to support the flexible pavement system. The numerical simulation concluded that the column installation to support flexible pavement reduced the heaving and differential settlement of the pavement effectively. Based on the previous research, this paper presents the result of performing a California Bearing Ratio (CBR) test on SiCC column-supported expansive soil. The research was aimed at investigating the $\mathrm{CBR}$ value of expansive soil supported with $\mathrm{SiCC}$ column, and to investigate the effect of water content and dry density on the CBR value.

\section{Experiment method}

The primary laboratory test in this study was California Bearing Ratio. The test was adopted from ASTM D1883 for soaked CBR test. In this study, two sets of specimens were prepared. The first set of specimens (assigned as Specimen A) was prepared at the wet side (the moisture is higher than the $\mathrm{OMC}$ ), and the second one (assigned as Specimen B) was prepared at the dry side (the moisture is lower than the OMC). Each set of specimens consisted of five specimens which were compacted at various moisture.

\subsection{Soils}

The soil used in this test was taken from Bangunjiwo Village, Kasihan District, Bantul Regency, Yogyakarta. Table 1 presents the engineering properties of the soil. The soil was classified as clay with high plasticity. The degree of the expansiveness of the soil has been investigated by Muntohar [13] as shown in Figure 1.

Table 1. The engineering properties of the soil

\begin{tabular}{|l|l|}
\hline Parameter & Value \\
\hline Specific gravity, $\mathrm{G}_{\mathrm{s}}$ & 2.59 \\
\hline Particle sizes distribution: & \\
Sand $(19.05 \mathrm{~mm}-75 \mu \mathrm{m})$ & $14 \%$ \\
Silt $(75-2 \mu \mathrm{m})$ & $65 \%$ \\
Clay $(<2 \mu \mathrm{m})$ & $21 \%$ \\
$\mathrm{D}_{50}$ & $27 \mu \mathrm{m}$ \\
\hline Atterberg limits: & \\
Liquid limit, LL & $73 \%$ \\
Plastic limit, PL & $40 \%$ \\
Plasticity index, PI & $32 \%$ \\
\hline Soil classification: USCS & $\mathrm{CH}$ \\
\hline Compaction: Standard Proctor & \\
Maximum dry density, MDD & $11.1 \mathrm{kN} / \mathrm{m}^{3}$ \\
Optimum moisture content, OMC & $30.4 \%$ \\
Unconfined compressive strength, $\mathrm{qu}_{\mathrm{u}}$ & $175.3 \mathrm{kPa}$ \\
CBR: & \\
Unsoaked & $2.6 \%-3.0 \%$ \\
Soaked & $<1 \%$ \\
\hline
\end{tabular}




\subsection{Specimen preparation}

A dry amount of 3-4 $\mathrm{kg}$ was mixed with water thoroughly to produce soil slurry. The slurry then was compacted in a CBR cylinder. The compaction energy was generated from the standard hammer of $2.5 \mathrm{~kg}$ weight. At the centre of the cylinder was installed a 2-inch PVC pipe (Fig. $2 \mathrm{a}$ and $2 \mathrm{~b}$ ) as the platform of SiCC column. The SiCC paste was poured and mixed into the preformed holes to form a column as shown in Fig. 2c. After the paste was hardened for about an hour (Fig. 2d), the specimen was covered with a sealed plastic bag and cured for a day at room temperature about $28^{\circ} \mathrm{C}$ for the subsequent soaking test.

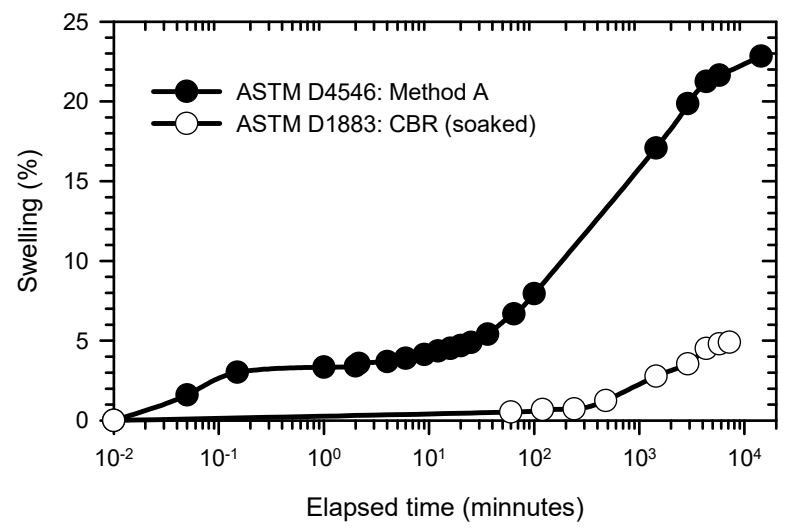

Fig. 1. Swelling behavior of the soil [14]

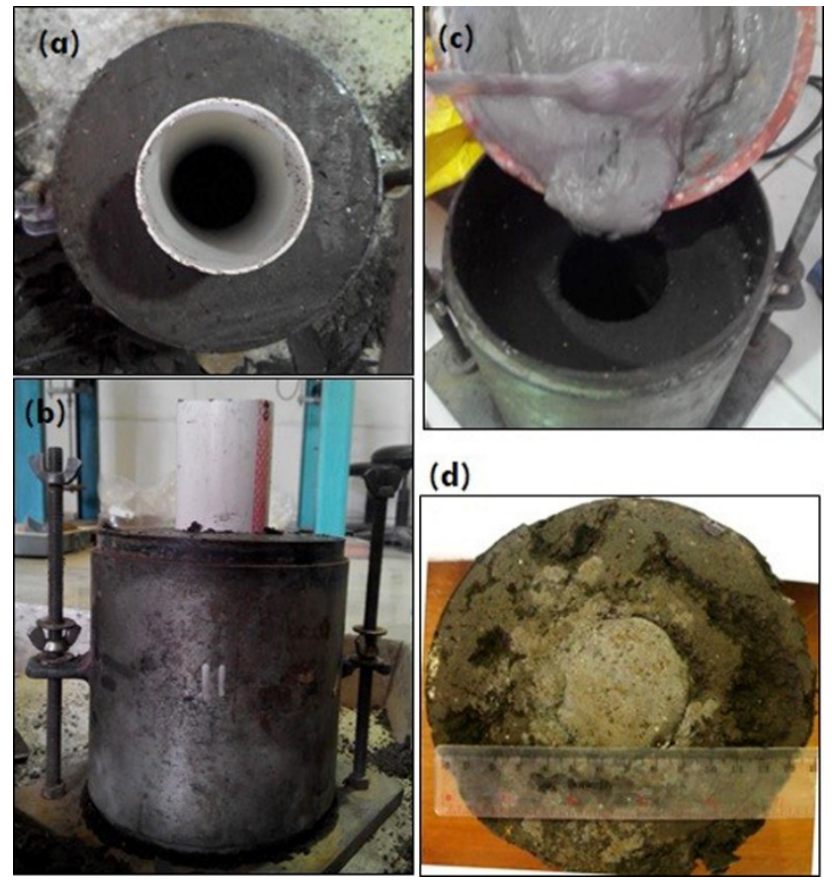

Fig. 2. Specimen preparation (a)-(b) soil compaction in CBR cylinder and column hole, (c) pouring $\mathrm{SiCC}$ paste in the hole, (d) SiCC column after hardening 


\subsection{Testing procedures}

Soaked-CBR tests were performed in the laboratory for all specimens. Before the penetration test, the specimen was immersed for four days to determine the swelling of the soil (Fig. 3). Before soaking, the dimension and weight of specimen were measured. The surcharge plate was placed on the specimen surface. The surcharge corresponds to the weight of the pavement layer. At least two pieces of seating plates (the sum of $2 \times 5 \mathrm{lbs}=10 \mathrm{lbs}$ ) were applied. The swelling during immersion was regularly recorded with elapsed time for four days. After four days of soaking, the specimen was prepared on the CBR machine for a penetration test. The California Bearing Ratio (CBR) is defined as determined in ASTM D1883-07 [16].

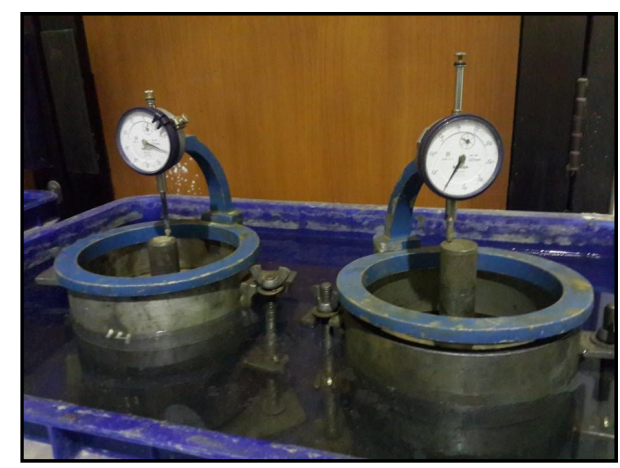

Fig. 3. The immersion of specimens for four days before CBR penetration test

\section{Results and discussion}

\subsection{Effect of moisture and dry density on the CBR}

In this study, the obtained CBR is the value of a compound between the SiCC column and the soil (composites system). The relationship between the CBR and the dry density, as well as the CBR and the moisture content, are shown as in Fig. 4a and 4b. The composite soilcolumn system has a range of CBR values between $3.5 \%$ to $14.5 \%$. These results are higher than the CBR of the untreated soil (see Table 1). The presence of the SiCC column increased the stiffness of soil. Thus, the soil has a higher resistance due to the load penetration. This result has been confirmed by previous research [12,15,17]. Furthermore, during the immersion, it was possible that the calcium $\left(\mathrm{Ca}^{2+}\right)$, and silica $\left(\mathrm{Si}^{2-}\right)$ ion from the SiCC paste migrate to the soil surrounding the column. This phenomenon then results in a pozzolanic reaction between the clay particles and the migrating ions. Finally, the reaction increased the soil strength in radial and vertical direction surrounding the column [7,8,9,17].

In Fig. 4a, the soil CBR value increases with the increase of soil density. The specimen A has a lower density than the specimen $B$, resulting in a lower CBR value than the specimen B. It has been known that the dry density is defined as the ratio between the dry mass of soil and soil volume. The dry density indicates a compact soil structure. A higher dry density implies a reduction in void ratio and increases the soil particle's interaction. This characteristic leads to increase bearing capacity [18]. The relationship between CBR and moisture content has characteristics such as the compaction curve, where the maximum CBR value is achieved at a certain moisture value as shown in Fig. $4 \mathrm{~b}$ and Fig. 5. In the composite soil-column, compacted column at the wet side (specimen A) yields a lower CBR value than the composite soil-column compacted dry side (specimen B). Moisture plays an essential role 
in controlling the particles' arrangement under the compactive effort. For a given compactive effort and dry density, the soil tends to be more flocculated for compaction on the dry side as compared to compaction on the wet side. At the wet side, the soil is more dispersive. The interparticle repulsions tend to increase with the increasing of moisture content, and resulting in a more orderly fabrics arrangement of the soil particles under a compactive effort. Theoretically, the flocculated fabrics arrangement has a higher soil strength than the dispersive. Cokca et al. [19] explained that the compacted clay behaves like a granular soil on the dry side of optimum water content thereby permitting the increase of the shear resistance.
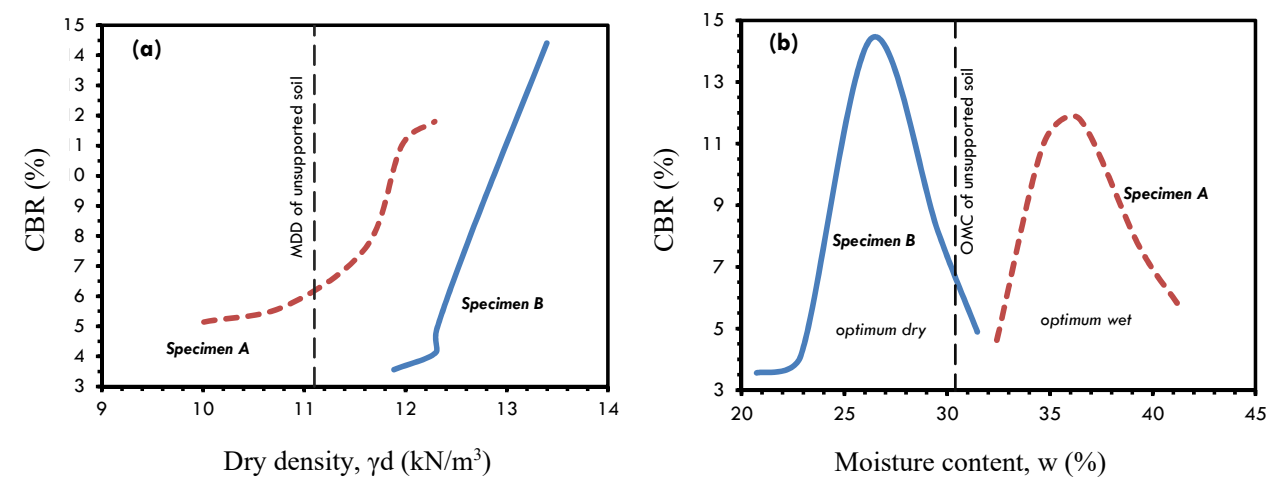

Fig. 4. Specimen preparation (a)-(b) soil compaction in CBR cylinder and column hole, (c) pouring $\mathrm{SiCC}$ paste in the hole, (d) SiCC column after hardening.

\subsection{Design CBR chart of SiCC column-improved subgrade for road pavement design}

In past several decades, CBR is a most useful parameter to determine the thickness of pavement layers for road pavement design. This section presents the discussion on a new design CBR chart for subgrade requirement. The CBR relationship as illustrated in Fig. 4a and $4 \mathrm{~b}$ shows a unique characteristic. Both groups of test specimens can produce the same CBR value despite having different water content. Thus, the relationship of the three parameters of CBR, the moisture content and the weight of the dry density can be shown in Fig. 5. The dashed lines in Fig. 5 represent the contour lines of CBR which are approximations of the same CBR values for each dry density and moisture content. The lowest CBR line is $6 \%$ as the requirements of subgrade according to SNI 1732-1989-F [20]. In the relationship, the CBR value tends to increase with increasing dry density and decreasing soil moisture content. The chart in Fig. 5 can be used to design the soil compaction work supported by SiCC columns, for example, to obtain a $\mathrm{CBR}=6 \%$, the subgrade can be compacted on the moisture conditions at points $\mathrm{A}, \mathrm{B}$, or $\mathrm{C}$. 


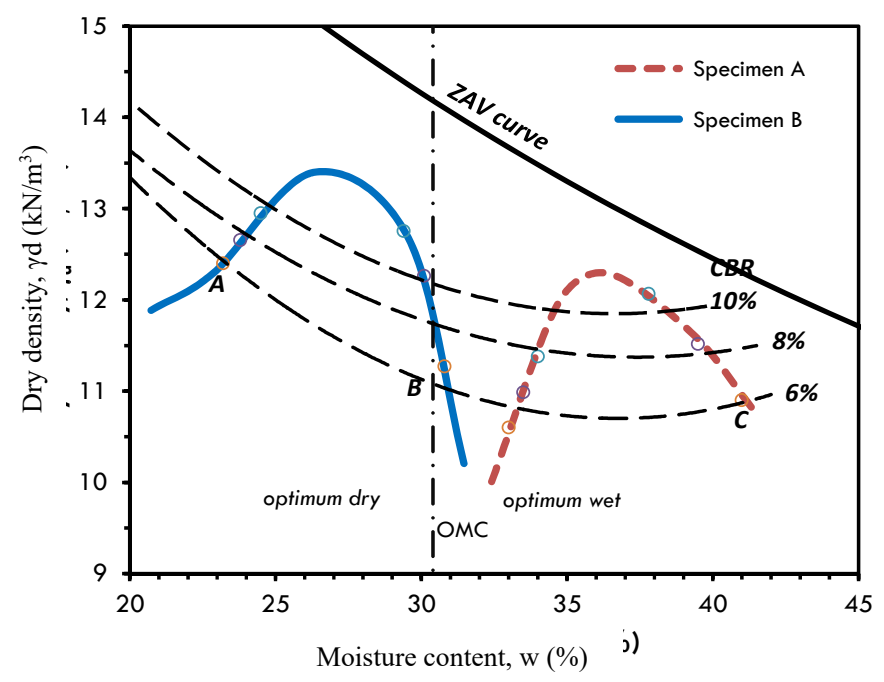

Fig. 5. Design CBR chart of the SiCC column-supported expansive subgrade.

\section{Conclusion}

The series of laboratory experiments have been successfully performed to investigate the effect of SiCC column on the CBR of expansive soil under soaking condition. The results and discussion showed that addition of SiCC column significantly increases the CBR. In general, the CBR value tends to increase with increasing the dry density and decreasing of soil moisture content. The CBR increase to about $14 \%$ on the dry side and $12 \%$ on the wet side of optimum moisture content. In addition, the research concludes that the compacted soil with SiCC column tends to have higher CBR if they are compacted on the dry side of optimum moisture content, thereby, permitting a higher dry density. Further research can be developed to seeking a comprehensive design CBR for road pavement.

This paper was financially granted through a research scheme of "Penelitian Unggulan Perguruan Tinggi" in 2014 according to the contract number 1314/K5/KM/2014. The author thanks for the research fund provided by The Ministry of Education and Culture, the Republic of Indonesia, and the Universitas Muhammadiyah Yogyakarta.

\section{References}

1. D. Widajat, Suherman, The Evaluation of Treatment Method of the Pavement Deterioration on Expansive Soil, Colloquium of Research and Development on Road and Bridge 2008, Road Research and Development Institute, Ministry of Public Work, 1-24, (2008), (in Indonesia)

2. S. Daud, M.I. Junica, M.E. Sunaryo, D. Pertiwi, A Study and Monitoring on the Fullscale Test of the Cakar Ayam Modifikasi, Colloquium of Research and Development on Road and Bridge 2009, Road Research and Development Institute, Ministry of Public Work, 244-284, (2009), (in Indonesia)

3. D.R. Prabowo, Economy Analysis of Flexible Pavement and Piled-Rigid Pavement on Babat-Bojonegoro Road Section, Final Year Project RC09 1380, Department of Civil Engineering, Institut Teknologi Sepuluh Nopember, Surabaya, (2010), (in Indonesia) 
4. J.P. Sahoo, P.K. Pradhan, Geotech. Geol. Eng. 28, 889-897, (2010)

5. A. Adam, I. Ibrahim, A. Alhardllo, A. Hadi, M. Ibrahim, Effect of hydrated lime on behavior of expansive soil as subgrade of flexible pavement structural system, Proceeding The 2nd International Conference on Sustainable Construction Materials: Design, Performance, and Application, 18-22 October 2012, Wuhan, China, 64-76, (2012)

6. A.S. Muntohar, Lime-column in expansive soil: A study on the compressive strength, Proceeding of the $1^{\text {st }}$ International Conference on Civil Engineering, 1-3 October 2003, Malang, East Java, (2003), (CD-ROM)

7. G.S. Budi, Civ. Eng. Dimens. 5(2), 99-102, (2003)

8. A.S. Muntohar, H.J. Liao, Strength distribution of the soil surrounding lime-column, In Chan, D., and Law, K.T. (Eds.): Proceeding 4th International Conference on Soft Soil Engineering, 2-6 October 2006, Vancouver, Canada, 315-319, (2006)

9. M.C. Tonoz, C. Gokceoglu, R., Ulusay, Bull. Eng. Geol. Environ. 62, 91-106, (2003)

10. C.D.F. Rogers, S. Glendinning, Eng. Geol. 47, 243-257, (1997)

11. A. Porbaha, K. Zen, M. Kobayashi, J. Infrastructure Sys. 5(1), 21-34, (1999)

12. H.G. Kempfert, Ground improvement methods with special emphasis on column-type techniques, In Vermeer, Schwiger, and Cudny (Eds.), Proceeding of International Workshop on Geotechnics of Soft Soil: Theory and Practice, Netherlands, Verlag Glückauf, 101-112, (2003)

13. A.S. Muntohar, App. Mech. Mat. 845, 62-69, (2016)

14. A. Nazef, H. Lee, S. Chun, J. Greene, Evaluation of Soil Stabilized Columns Used for Flexible Pavement Embankment Support and Settlement Control, Report No. FL/DOT/SMO/13-561 Department of Transportation State of Florida, (2013).

15. A.S. Muntohar, Saputro, S.A., The SiCC Column Improved the Expansive Clay, Proceeding of the 14th International Conference on QIR (Quality in Research), 10-13 August 2015, Lombok, Indonesia, 38-44, (2015)

16. ASTM D1883 - 07e2, 2011. Standard Test Method for CBR (California Bearing Ratio) of Laboratory-Compacted Soils, ASTM International, West Conshohocken, PA, (2011)

17. A.A. Abiodun, Z. Nalbantoglu, Can. Geotech. J. 52, 1-9, (2015)

18. T.F. Yideti, B. Birgisson, D. Jelagin, Road Mater. Pavement Des. 15(1), 102-113, (2014)

19. E. Cokca, O. Erol, F. Armangil, Geotech. Geol. Eng. 22, 285-297, (2004)

20. SNI 1732-1989-F, Road Pavement Design using Component Analysis Method, Nasional Standard Agency, Jakarta, (1989), (in Indonesia) 